\title{
LIMBAH RANTING, DAUN, DAN BUNGA KERING SEBAGAI MATERIAL PENCIPTAAN KARYA RUSTIC WOOD SLICE
}

\author{
Swastika Dhesti Anggriani ${ }^{1}$ \\ (Jurusan Seni dan Desain, Fakultas Sastra, Universitas Negeri Malang, swastikadhestia@gmail.com, \\ swastikadhesti.fs@um.ac.id, 081803661376) \\ Lisa Sidyawati² \\ (Jurusan Seni dan Desain, Fakultas Sastra, Universitas Negeri Malang, lisa.sidyawati.fs@um.ac.id, 085258864977) \\ Abdul Rahman Prasetyo ${ }^{3}$ \\ (Jurusan Seni dan Desain, Fakultas Sastra, Universitas Negeri Malang, prasetyo.fs@um.ac.id, 089678185369) \\ Elvira Kurnia Ramadhani ${ }^{4}$ \\ (Jurusan Seni dan Desain, Fakultas Sastra, Universitas Negeri Malang, elvirakurniaramadhani@gmail.com, 082332691043)
}

\begin{abstract}
The purpose of designing this rustic wood slice artwork with the basic material of waste branches, leaves, and dried flowers is to create new artwork and develope the skills of productive communities in Watu Gong, Malang City, East Java. This rustic wood slice is a artwork that can be used as decorative objects, used objects, and souvenirs for visitors of The Watu Gong. The method used in this study is method of craft creation which consist of 3 stages including exploration, design, and realization of actualization. The exploration phase starts from observing natural resources, such as wood, branches, leaves, and flowers which can be processed into basic materials for making rustic wood slice artwork. At the design stage, several sketches were made as an alternative design. From these alternative, one design sketch was chosen which was turned into an actual artwork. The realization or actualization stage is carried out by several processes, including preparation of tools and materials, exploration main materials and supporting materials placement, and actualization of the actual artwork. The results of this creation are 2 types of rustic wood slice artwork, namely rustic wood slice jar and rustic wood slice mirror.
\end{abstract}

Keywords: rustic, wood slice, waste materials, kriya

\section{ABSTRAK}

Tujuan perancangan karya rustic wood slice dengan bahan dasar limbah ranting, daun, dan bunga kering ini adalah menciptakan karya baru dan mengembangkan keterampilan masyarakat produktif di daerah Watu Gong, Kota Malang, Jawa Timur. Karya rustic wood Slice ini merupakan salah satu karya yang dapat dijadikan sebagai benda hias, benda pakai, dan souvenir bagi pengunjung objek wisata Watu Gong yang ada di daerah ini. Metode penciptaan yang digunakan adalah metode penciptaan seni kriya yang mencakup 3 tahapan, yaitu eksplorasi, perancangan, dan pewujudan. Tahap eksplorasi dimulai dari pengamatan sumber daya alam, seperti kayu, ranting, daun, dan bunga yang dapat diolah menjadi bahan dasar pembuatan karya rustic wood slice. Pada tahap perancangan, dibuat beberapa gambar sketsa desain sebagai alternatif desain. Dari beberapa alternatif desain tersebut dipilih 1 gambar sketsa yang akan diwujudkan menjadi karya sebenarnya. Tahap pewujudan dilakukan melalui beberapa proses, yaitu persiapan alat dan bahan, eksplorasi peletakan material utama dan material pendukung, serta pewujudan karya sebenarnya. Hasil penciptaan berupa dua jenis karya rustic wood slice, yaitu toples rustic wood slice dan kaca cermin rustic wood slice.

Kata Kunci: rustic, wood slice, limbah, kriya 


\section{PENDAHULUAN}

Di Kota Malang, banyak terdapat bangunan cagar budaya dan situs bersejarah, baik berupa bangunan kolonial maupun situs peninggalan kerajaan. Salah satu wilayah yang memiliki situs bersejarah adalah wilayah Tlogomas, yang memiliki Situs Watugong. Situs ini merupakan salah satu potensi fisik yang dapat dikembangkan, salah satunya bidang pariwisata. Potensi fisik ini juga didukung oleh potensi nonfisik, seperti akses jalan yang mudah, serta masyarakatnya yang memiliki keinginan kuat untuk mengembangkan potensinya (Prima Sworo, 2017).

Sebagai wilayah yang menjadi bagian dari Kota Malang, Jalan Watu Gong memiliki potensi alam yang umum ditemukan pada wilayah perkotaan. Salah satunya berasal dari pohon dan tumbuhan lain. Batang pohon berukuran besar seringkali tidak dimanfaatkan kembali dan hanya dibiarkan sebagai limbah tak terpakai. Hal yang sama juga terjadi pada ranting dan daun kering yang sering dibiarkan begitu saja menjadi limbah. Padahal, jika diolah kembali, bisa menjadi produk kreatif yang dapat menambah nilai fungsi dan ekonominya. Produk-produk yang memanfaatkan limbah batang kayu, ranting, dan daun kering saat ini dikenal dengan produk bergaya rustic. Gaya ini menjadi semakin populer beberapa tahun terakhir karena digunakan dalam berbagai produk, seperti furnitur, aksesori ruangan, dan souvenir.

Gaya rustic atau dikenal juga sebagai gaya 'pedesaan' adalah gaya yang menghadirkan elemen-elemen natural dari alam yang mengandung unsur budaya daerah, sehingga pengguna secara tidak langsung juga dapat mengenal budaya yang akan ditampilkan (Kabinani \& Santosa, 2014). Finishing Rustic dapat mencerminkan kesan tua, alami, dan kaya akan material alam (Jayanti et al., 2014). Penggunaan material kayu sangat ditonjolkan dalam produk yang menggunakan gaya rustic
(Riadi, 2015). Selain itu, gaya rustic juga memiliki ciri khas menampilkan tekstur material, seperti material kayu (Dian, 2017). Berdasarkan beberapa pendapat tersebut, dapat disimpulkan bahwa gaya rustic adalah gaya yang menampilkan kesan alami/natural dengan penggunaan material yang bersumber dari alam, seperti kayu.

Pada perkembangannya, karya seni kriya saat ini juga mulai menggunakan gaya rustic sebagai dasar perancangan yang lebih indah dan unik. Dengan memanfaatkan limbah yang berasal dari alam di lingkungan sekitar, karya kriya juga dapat dibuat menjadi lebih indah dan memiliki nilai fungsi yang lebih. Salah satu limbah yang mudah ditemukan adalah potongan batang pohon. Kayu dari batang pohon dapat dipotong dengan ketebalan 1-1,5 $\mathrm{cm}$, atau sering disebut sebagai wood slice.

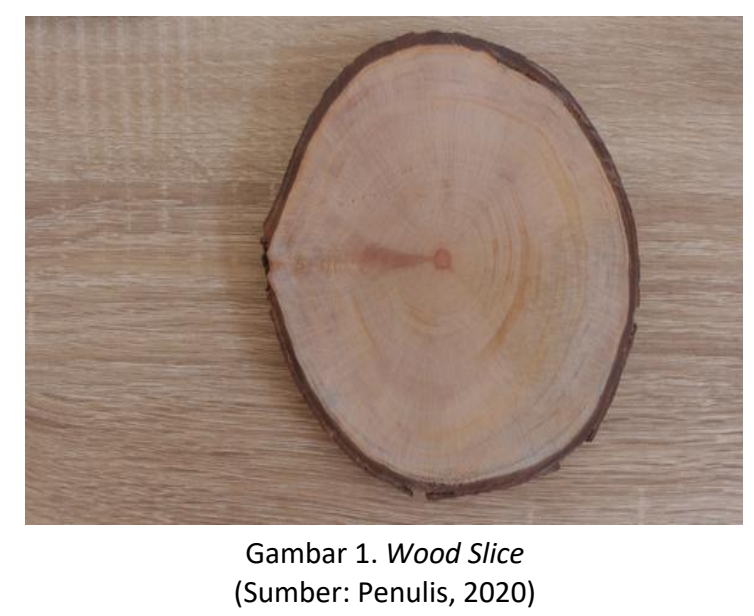

Selain wood slice sebagai material utama yang dapat dimanfaatkan, ranting, daun, dan bunga yang telah dikeringkan juga dapat dijadikan sebagai material membuat souvenir gaya rustic. Tidak ada ketentuan jenis ranting, daun, dan bunga yang dapat digunakan sebagai material membuat souvenir gara rustic ini. Semua ranting, daun, dan bunga yang berasal dari lingkungan sekitar dapat dimanfaatkan sebagai material. 


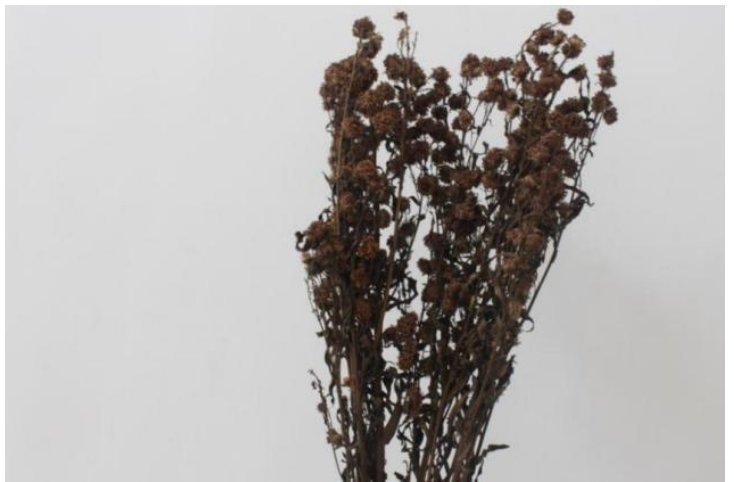

Gambar 2. Ranting, Daun, dan Bunga Pikok Ungu yang Dikeringkan

(Sumber: Penulis, 2020)

Berdasarkan penjelasan di atas, dapat disimpulkan bahwa masih terdapat potensi yang dapat dikembangkan secara lebih maksimal, khususnya di wilayah Jalan Watu Gong. Salah satu potensi tersebut berasal dari alam sekitar. Potensi alam didukung dengan kemampuan masyarakakat usia produktif dapat menjadi langkah awal pengembangan kreativitas pembuatan karya kriya bergaya rustic ini. Karya kriya dianggap mampu memberikan nilai sosial dan ekonomi bagi masyarakat yang memproduksi atau membuatnya. Hal ini karena kriya berkembang sesuai dengan masanya. Saat ini kriya memiliki peran dalam masyarakat kontemporer maupun tradisional (Wicaksono dan Purwandari, 2020). Karya kriya bergaya rustic dibuat menggunakan material utama potongan kayu (wood slice), ranting, daun, dan bunga kering yang mudah ditemukan di alam sekitar.

Pembuatan karya kriya ini merupakan salah satu upaya untuk menghasilkan produk kriya baru dengan memanfaatkan potensi daerah Jalan Watu Gong. Upaya pembuatan karya kriya ini diharapkan dapat mendorong kreativitas masyarakat usia produktif di Jalan Watu Gong dalam membuat produk-produk kriya yang diminati oleh masyarakat luas saat ini.

\section{METODE}

Sebuah karya seni yang menghasilkan suatu produk kriya dapat diciptakan melalui proses yang menggunakan intuisi penciptanya. Akan tetapi, penciptaan karya seperti ini dapat dilakukan dengan metode ilmiah yang direncanakan secara sistematis dan teliti. Metode serta alat khusus bagi peneliti yang berbasis praktik dalam bentuk tulisan atau karya ilmiah, seperti seni dan desain disebut sebagai pendekatan practice-based research (Hendriyana dalam Asmara dan Meilani, 2020). Menurut Gray dan Malins, penelitian di bidang seni memiliki karakteristik menggunakan banyak pendekatan dan beragam metode yang disesuaikan dengan penelitian karya seni yang dibuat oleh masing-masing individu (Asmara dan Meilani, 2020).

Metodologi yang digunakan pada penciptaan karya rustic wooden slice ini adalah metode penciptaan seni kriya. Metodologi penciptaan seni kriya yang digunakan pada penciptaan produk rustic wood slice ini meliputi 3 tahapan, yaitu eksplorasi, perancangan, dan pewujudan (Gustami, 2007: 329).

\section{Eksplorasi}

Tahap pertama adalah tahap eksplorasi. Tahap eksplorasi adalah aktivitas menggali ide yang dilakukan melalui proses identifikasi dan perumusan masalah. Proses tersebut meliputi penelusuran, penggalian, pengumpulan data dan sumber referensi, yang kemudian dilanjutkan dengan proses analisis data untuk mendapatkan kesimpulan. Kesimpulan ini yang akan digunakan untuk menjadi solusi dalam perancangan (Gustami, 2007: 329-330). Pada tahapan ini penulis melakukan pengamatan langsung di lapangan untuk melihat potensi Sumber Daya Alam (SDA) yang dapat diolah kembali untuk dijadikan material pembuatan karya. Selain itu, penulis juga melakukan pengamatan karya serupa yang sedang digemari oleh masyarakat 
melalui media internet, seperti instagram. Adapun penjelasan tahapan eksplorasi yang dilakukan oleh peneliti adalah sebagai berikut.

a. Mengumpulkan informasi melalui studi pustaka tentang karya seni yang menggunakan gaya rustic untuk menambah pengalaman estetika penulis yang akan dituangkan dalam tahap perancangan karya dan diwujudkan dalam bentuk karya jadi.

b. Mengamati langsung ke lapangan untuk melihat Sumber Daya Alam (SDA) yang potensial untuk diolah kembali menjadi bahan dasar membuat karya rustic wood slice

c. Mengembangkan imajinasi yang bersumber dari pengalaman estetika dan artistik untuk mendapatkan ide kreatif tentang pengolahan limbah menjadi bahan dasar pembuatan karya

\section{Perancangan}

Tahap kedua adalah tahap perancangan. Menurut SP. Gustami (2007) di dalam bukunya yang berjudul Butir-Butir Mutiara Estetika Timur menjelaskan bahwa tahap perancangan dibangun berdasarkan perolehan poin-poin penting dari hasil analisis yang telah dirumuskan. Poin-poin penting ini kemudian divisualisasikan dalam bentuk beberapa alternatif gambar sketsa. Dari beberapa gambar sketsa tersebut akan dipilih sketsa terbaik sebagai acuan reka bentuk atau gambar teknik yang akan diwujudkan menjadi karya. Pengertian lain menurut Kamus Besar Bahasa Indonesia (2008: 927), perancangan berasal dari kata rancang yang berarti desain. Perancangan diartikan sebagai proses dan cara pembuatan, sedangkan merancang adalah mengatur segala sesuatu (sebelum bertindak, mengerjakan, atau melakukan sesuatu). Pada tahap ini, penulis akan membuat tiga rancangan gambar sketsa dari masing-masing produk yang kemudian akan dipilih salah satunya untuk diwujudkan menjadi sebuah karya. Gambar sketsa dipilih berdasarkan beberapa pertimbangan yang telah dirumuskan oleh penulis.

Berikut alternatif gambar sketsa yang dibuat oleh penulis.
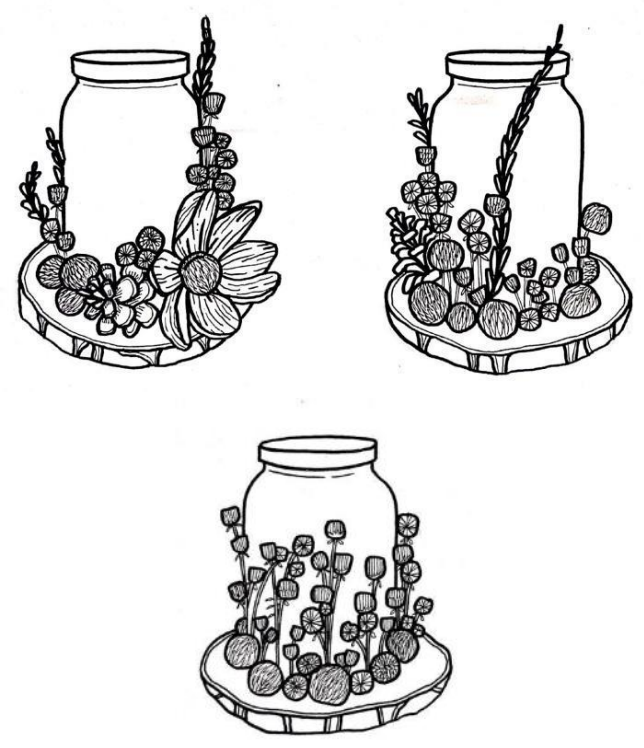

Gambar 3. Alternatif Gambar Sketsa Produk 1 (Sumber: Penulis, 2020)
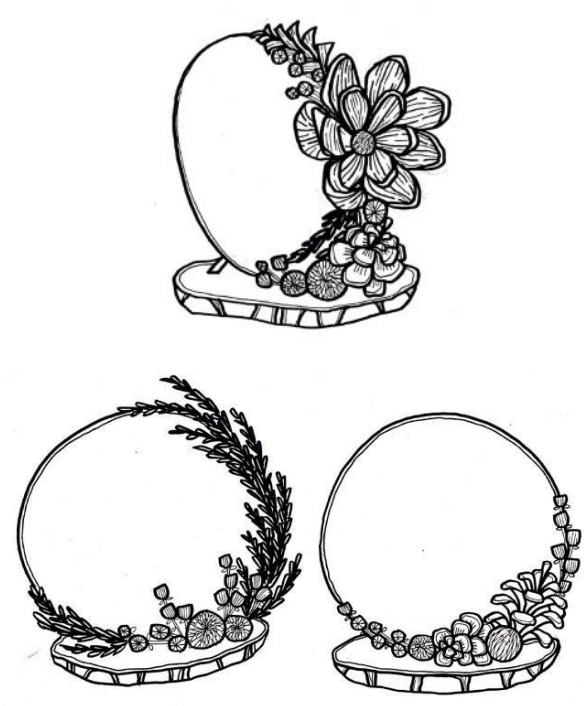

Gambar 4. Alternatif Gambar Sketsa Produk 2 (Sumber: Penulis, 2020)

Berdasarkan alternatif gambar sketsa di atas, dipilihlah salah satu gambar yang akan diwujudkan menjadi karya. Sebelum proses 
mewujudkan gambar sketsa menjadi karya yang sesungguhnya, terlebih dahulu penulis akan melakukan eksperimen untuk mengeksplorasi alat dan bahan, sehingga diperoleh hasil yang diinginkan oleh penulis.

\section{Pewujudan}

Tahap ketiga adalah tahap pewujudan. Pewujudan adalah tahap pengalihan dari gagasan berupa gambar sketsa yang terpilih menjadi bentuk karya seni yang diinginkan (Gustami, 2007: 333). Tahap pewujudan meliputi persiapan alat dan bahan, proses pembuatan, dan proses finishing. Penulis akan menjabarkan alat dan bahan serta proses pembuatan dan finishing secara sederhana. Pada tahap ini, telah terpilih satu gambar sketsa yang akan diwujudkan menjadi karya sebenarnya.

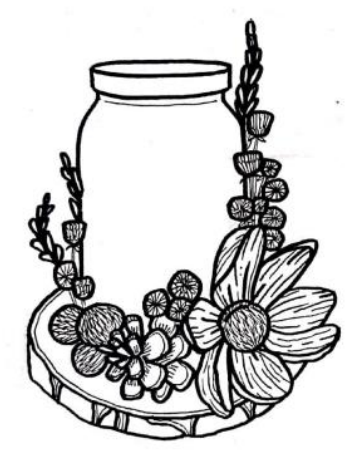

Gambar 5. Gambar Sketsa Terpilih Produk 1 (Sumber: Penulis, 2020)

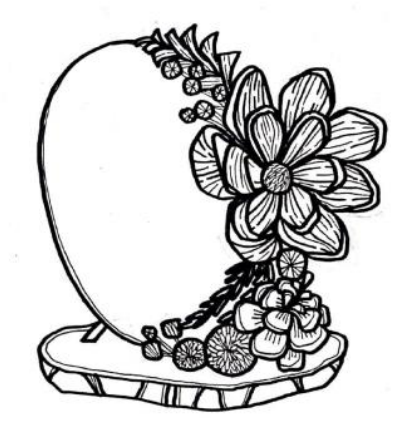

Gambar 6. Gambar Skestsa Terpilih Produk 2 (Sumber: Penulis, 2020)

\section{HASIL DAN PEMBAHASAN}

\section{a. Proses Perwujudan}

Mewujudkan atau merealisasikan karya seni adalah proses yang dilakukan oleh penulis dengan mengaplikasikan konsep dan ide ke dalam karya seni. Pada tahap pewujudan ini, penulis membuat pengembangan gambar sketsa secara lebih detail dari gambar sketsa yang telah terpilih. Gambar sketsa detail berisi gambar penempatan objek utama dan objek pendukung. Gambar dibuat secara manual bagian demi bagian kemudian disusun menjadi satu bagian utuh. Dibutuhkan beberapa hal dalam melaksanakan proses perwujudan ide penciptaan menjadi sebuah karya, yaitu persiapan alat dan bahan, eksplorasi penataan objek utama dan objek pendukung, serta aktualisasi atau mewujudkan gambar sketsa menjadi karya sebenarnya.

\section{1) Persiapan Alat dan Bahan}

Alat dan bahan yang dibutuhkan untuk membuat karya 1 antara lain wood slice, toples diameter $10 \mathrm{~cm}$ dan tinggi 14 $\mathrm{cm}$, serta cermin diameter $20 \mathrm{~cm}$, alat lem tembak dan lilin lem tembak, gunting, bunga dari klobot jagung, bunga pinus kering, bunga genggeyan atau kumori kering, bunga jagung kering, bunga baby breath kering, dan bunga pikok ungu kering. Jumlah bunga kering dan ukurannya disesuaikan dengan ketersediaan tempat pada permukaan atas wood slice.

\section{2) Eksplorasi Peletakan Objek Utama dan} Objek Pendukung

Eksplorasi peletakan objek utama dan objek pendukung yang dilakukan oleh penulis merupakan kegiatan untuk menguji coba peletakan material utama dan material pendukung. Material utama pada karya 1 adalah wood slice dan toples, sedangkan material utama pada karya 2 adalah wood slice dan kaca cermin. Untuk 
material pendukung pada kedua karya tersebut adalah bunga dari klobot jagung, bunga pinus kering, bunga genggeyan atau kumori kering, bunga jagung kering, bunga baby breath kering, dan bunga pikok ungu kering.

Tahap pertama yang dilakukan oleh penulis adalah meletakkan material utama, seperti toples dan cermin ke atas permukaan wood slice. Setelah material utama tertata menjadi satu, selanjutnya dilakukan uji coba peletakan material pendukung di sekitar material utama.

\section{3) Pewujudan Karya Sebenarnya}

Proses perwujudan karya merupakan tahap aktualisasi dari gambar sketsa desain yang sudah pasti terpilih. Di dalam proses pembuatan karya rustic wood slice ini, penulis akan melalui beberapa proses, antara lain menempel material pendukung secara permanen dengan lem perekat, merekatkan bunga, ranting dan daun, memastikan semua material tertempel kuat di permukaan wood slice dan toples atau cermin, dan finishing akhir membersihkan sisa lem yang mengotori karya.

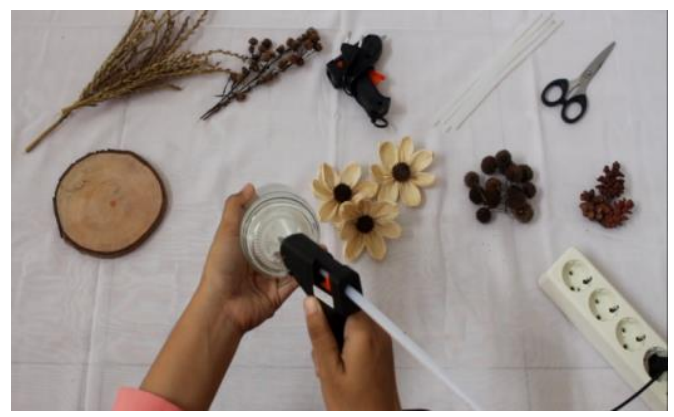

Gambar 7. Proses Menempelkan Material Utama (Sumber: Penulis, 2020)

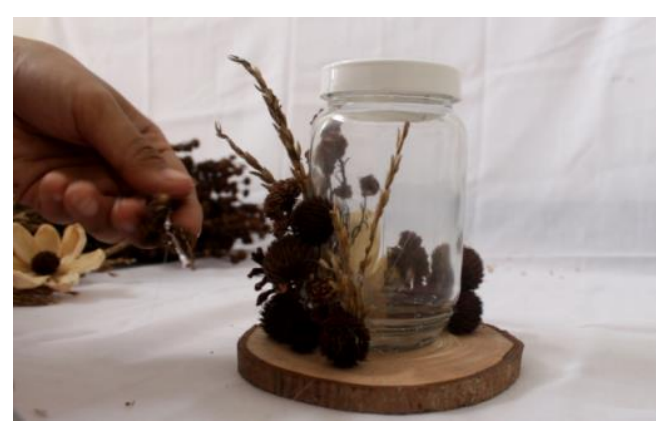

Gambar 8. Proses Menempelkan Material Pendukung

(Sumber: Penulis, 2020)

\section{b. Hasil Karya}

\section{1) Karya 1}

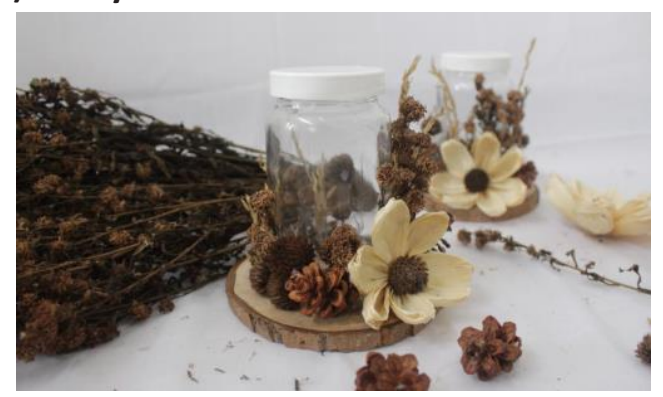

Gambar 9. Karya Toples Rustic Wood Slice (Sumber: Penulis, 2020)

Judul : Rustic Wood Slice - Jar

Ukuran : 13, $5 \mathrm{~cm}$ (diameter wood slices) $\times 14 \mathrm{~cm}$

Media : wood slice, toples kaca

(diameter $7 \mathrm{~cm}$, tinggi $13 \mathrm{~cm}$ ), ranting kering, bunga dari klobot jagung, bunga pinus kering, bunga genggeyan atau kumori kering, bunga jagung kering, bunga baby breath kering, dan bunga pikok ungu kering

Batang pohon, ranting, daun, dan bunga merupakan material yang mudah ditemukan di alam. Akan tetapi, materialmaterial tersebut seringkali dibiarkan begitu saja dan tidak terpakai atau tidak diolah kembali. Rustic wood Slice - Jar merupakan karya kriya yang memanfaatkan sumber daya alam untuk diolah kembali menjadi material utama 
dan material pendukung pembuatan karya. Kesan yang ingin ditimbulkan dari pemilihan materialnya adalah kesan alami, kasar, dan tidak di-finishing dengan baik. Hal ini sesuai dengan pengertian gaya rustic yang saat ini banyak digunakan dalam berbagai macam karya seni. Toples dipilih sebagai salah satu material utama karena pertimbangan aspek fungsi yang tidak hanya sebagai elemen hias tetapi dapat juga digunakan sebagai benda pakai, seperti tempat meletakkan makanan, aksesori kecil, dan tempat air.

\section{2) Karya 2}

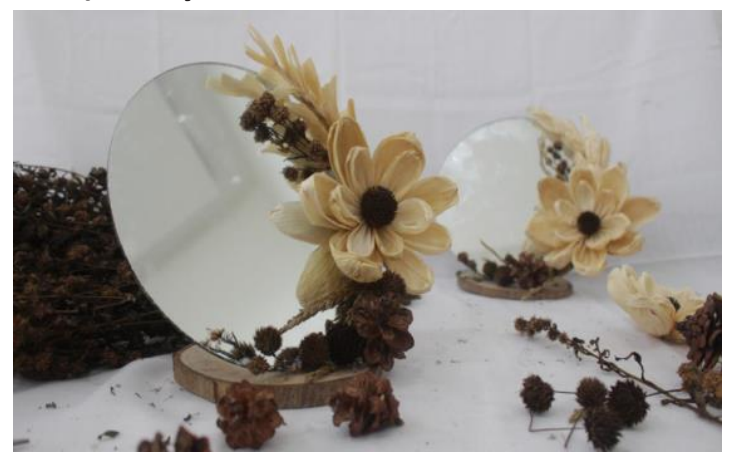

Gambar 10. Karya Kaca Cermin Rustic wood Slice (Sumber: Penulis, 2020)

Judul : Rustic Wood Slice - Mirror

Ukuran : 13, $5 \mathrm{~cm}$ (diameter wood slices) $\times 19 \mathrm{~cm}$

Media : wood slice, toples kaca (diameter $7 \mathrm{~cm}$, tinggi $13 \mathrm{~cm}$ ), ranting kering, bunga dari klobot jagung, bunga pinus kering, bunga genggeyan atau kumori kering, bunga jagung kering, bunga baby breath kering, dan bunga pikok ungu kering

Batang pohon, ranting, daun, dan bunga merupakan material yang mudah ditemukan di alam. Akan tetapi, materialmaterial tersebut seringkali dibiarkan begitu saja dan tidak terpakai atau tidak diolah kembali. Rustic wood Slice - Mirror merupakan karya kriya yang memanfaatkan sumber daya alam untuk diolah kembali menjadi material utama dan material pendukung pembuatan karya. Kesan yang ingin ditimbulkan dari pemilihan materialnya adalah kesan alami, kasar, dan tidak di-finishing dengan baik. $\mathrm{Hal}$ ini sesuai dengan pengertian tentang gaya rustic yang saat ini banyak digunakan dalam berbagai macam karya seni. Kaca cermin dipilih sebagai salah satu material utama karena pertimbangan aspek fungsi, seperti aksesori interior ruang atau cermin yang dapat digunakan.

\section{PENUTUP}

Penciptaan karya rustic wood slice seperti toples dan kaca cermin memiliki fungsi sebagai elemen hias dan benda pakai. Penggunaan kembali limbah ranting dan bunga kering pada karya ini merupakan upaya untuk pemanfaatan kembali material yang sebelumnya tidak memiliki nilai fungsi menjadi karya yang dapat digunakan. Material utama yang digunakan ialah wood slice atau potongan kayu tipis dari batang pohon yang sudah tidak dapat digunakan untuk material produk lain. Jenis limbah kayu yang dapat dibuat menjadi wood slice adalah kayu jenis apapun, sehingga material utama ini mudah ditemukan di lingkungan sekitar. Material utama lainnya yang dapat memberi nilai tambah pada karya ialah toples kaca dan kaca cermin. Material utama ini dapat disesuaikan dengan kebutuhan dan konsep karya yang ingin dibuat. Material utama lain yang dapat digunakan, seperti jam dinding, mangkok, atau botol. Material pendukung yaitu ranting, bunga dari klobot jagung, bunga pinus kering, bunga genggeyan atau kumori kering, bunga jagung kering, bunga baby breath kering, dan bunga pikok ungu kering. Pemilihan material pendukung ini juga 
dapat disesuaikan dengan material yang tersedia di alam sekitar.

Karya rustic wood slice ini dibuat melalui beberapa tahapan, yaitu eksplorasi, perancangan, dan pewujudan. Pada tahap eksplorasi, dilakukan penggalian ide melalui sumber pustaka cetak, online, dan survei lapangan. Pada tahap perancangan dibuat beberapa gambar sketsa alternatif yang berisi ide gagasan yang kemudian dipilih satu gambar sketsa untuk diwujudkan menjadi karya sebenarnya. Pada tahap pewujudan, dilakukan persiapan alat dan bahan, eksplorasi peletakan material utama dan material pendukung, serta pewujudan karya.

Hasil karya yang dibuat berjumlah dua jenis karya, yaitu toples rustic wood slice dan kaca cermin rustic wood slice. Wujud hasil karyanya berupa karya rustic yang memiliki ciri khas alami, kasar, dan seperti tidak di-finishing dengan baik.

\section{Daftar Pustaka}

Asmara, Dwita A. dan Meilani, Sarasati. 2020. "Lampu Hias dengan Dekorasi Motif Batik Parang dan Kawung Inovasi Penciptaan Keramik". CORAK Jurnal Seni Kriya Vol.9, No.1, hal. 1-16.

Depdiknas. 2008. Kamus Besar bahasa Indonesia. Jakarta: Balai Pustaka.

Dian. 2017. "Hotel Butik di Kota Singkawang". Jurnal Online Mahasiswa Arsitektur Universitas Tanjungpura, 5 (September 2017), hal. 50-63.

Jayanti, E. D. dan Honggowidjaja, S. P. 2014. "Aplikasi Finishing Rustic Style untuk Galeri, Kafe, dan Retail". Jurnal INTRA, 2(2), hal. 630-633.

Kabinani, A. S., \& Santosa, A. 2014. "Perancangan Interior Kafe dengan Tema Adat Perkawinan di Kupang (NTT)". Jurnal INTRA, 2(2), hal. 520-526.

Prima Sworo, R. A. 2017. "Perencanaan dan Perancangan Kampung Wisata Watu Gong Kelurahan Tlogomas Rw 03 Kecamatan Lowokwaru Kota Malang".
JAST : Jurnal Aplikasi Sains Dan Teknologi, 1(1), hal. 17-29.

Riadi, Yussy. 2015. "Perancangan Interior Hotel Resort Pines Garden di Tretes, Pasuruan, Jawa Timur". Jurnal INTRA, 3(1), hal. 3338.

SP Gustami. (2007). Butir-butir estetika Timur Ide Dasar Penciptaan Karya seni Kriya Indonesia. Yogyakarta: Prasista.

Wicaksono, A. dan Purwandari, R. 2020. "Penggunaan Limbah Kulit Samak Krom pada Kemasan Produk Olahan Kayu Gaharu". CORAK Jurnal Seni Kriya Vol.9, No.1, hal. 75-86. 